\title{
Fish larvae assemblages in two floodplain lakes with different degrees of connection to the Paraná River, Brazil
}

\author{
Vanessa Salete Daga ${ }^{1}$, Tatiane Mary Gogola ${ }^{1}$, Paulo Vanderlei Sanches ${ }^{1,2}$, \\ Gilmar Baumgartner ${ }^{1,3}$, Dirceu Baumgartner ${ }^{3,4}$, Pitágoras Augusto Piana ${ }^{1,3}$, \\ Éder André Gubiani ${ }^{1,3}$ and Rosilene Luciana Delariva ${ }^{5}$
}

The objective of this study was to assess the abundance, attributes of assemblages, and spatial and temporal distributions of fish larvae and their relationships with some abiotic variables in two floodplain lakes with different degrees of connection to the Paraná River in Ilha Grande National Park, PR, Brazil. Four sampling sites were chosen, two in each floodplain lake. Night samples were taken with plankton nets during three spawning seasons (monthly, from October to March) from 2001 to 2005. The highest diversity and abundance were recorded at Saraiva Lake, with 25 taxa being identified. In Xambrê Lake, only sedentary species were captured, and the most abundant species were Plagioscion squamosissimus and Hypophthalmus edentatus. The greatest abundance of larvae was found in the second spawning season. In the Saraiva Lake, the most abundant species were Moenkhausia aff. intermedia, Hyphessobrycon sp., and Bryconamericus stramineus, but larvae of known migratory species were also documented. In this lake, the greatest abundance of larvae was found in the third spawning. Larvae abundance was influenced by water temperature and conductivity. The high diversity and abundance recorded in Saraiva Lake may be a result of its connectivity with the Paraná River, and the low diversity and abundance observed at Xambrê Lake are likely due to its isolation from the river. This work shows the importance of these lagoons for fish development, for both sedentary and migratory species. Both lagoons may be considered to have extreme ecological importance and they are also extremely susceptible to impacts, so any careless disturbance may cause irreversible damage.

Este trabalho teve por objetivo avaliar a abundância, os atributos da assembleia e a distribuição espacial e temporal de larvas de peixes, bem como a relação dessas variáveis com alguns fatores abióticos, em duas lagoas com diferentes graus de conexão com o rio Paraná, Parque Nacional de Ilha Grande, PR, Brasil. As amostragens foram realizadas em quatro locais, dois em cada lagoa. As coletas foram realizadas mensalmente à noite durante três períodos de desova (outubro a março) de 2001 a 2005, com o auxílio de redes de plâncton. A maior diversidade e abundância foram verificadas na lagoa Saraiva, sendo identificados 25 táxons. Na lagoa Xambrê somente foram capturadas espécies sedentárias e as mais abundantes foram Plagioscion squamosissimus e Hypophthalmus edentatus. Nessa lagoa as maiores ocorrências foram verificadas no período II. Na lagoa Saraiva as maiores capturas foram de Moenkhausia aff. intermedia, Hyphessobrycon sp. e Bryconamericus stramineus, entretanto, larvas de espécies migradoras também foram registradas. Nessa lagoa, as maiores ocorrências foram no período III. A abundância de larvas foi influenciada pela temperatura da água e pela condutividade elétrica. A elevada diversidade e abundância registradas na lagoa Saraiva podem ser atribuídas a sua conectividade com o rio Paraná, enquanto que a baixa diversidade e abundância observadas na lagoa Xambrê podem estar relacionadas ao seu isolamento. Os resultados obtidos com este estudo demonstram a importância das lagoas marginais para o desenvolvimento inicial dos peixes, tanto para

\footnotetext{
${ }^{1}$ Pós-Graduação em Recursos Pesqueiros e Engenharia de Pesca, Universidade Estadual do Oeste do Paraná, Campus de Toledo, Rua da Faculdade, 645, 85903-000 Toledo, PR, Brazil. vanedaga@yahoo.com.br (VSD); tatigogola@yahoo.com.br (TMG)

${ }^{2}$ Departamento de Biologia, Universidade Paranaense, Av. Parigot de Souza, 3636, 85903-170 Toledo, PR, Brazil. Programa de PósGraduação em Biotecnologia Aplicada à Agricultura, Universidade Paranaense, Praça Mascarenhas de Moraes S/N, Umuarama, PR, Brazil. pvs@unipar.br

${ }^{3}$ Centro de Engenharias e Ciências Exatas, Gerpel, Universidade Estadual do Oeste do Paraná, Rua da Faculdade, 645, 85903-000 Toledo, PR, Brazil.gilmar_baum@yahoo.com.br (GB); pitapiana@yahoo.com.br (PAP); egubiani@yahoo.com.br (EAG)

${ }^{4}$ Programa de Pós-Graduação em Ecologia de Ambientes Aquáticos Continentais, Universidade Estadual de Maringá, Av. Colombo, 5790, 87020-900 Maringá, PR, Brazil. baum.d@hotmail.com

5Departamento de Biologia, Centro Universitário de Maringá, Av. Guedner, 1610, 87050-900 Maringá, PR, Brazil. rldelariva@uol.com.br
} 
espécies sedentárias como migradoras. Ambas as lagoas podem ser consideradas de extrema importância ecológica e altamente susceptíveis a impactos, onde qualquer interferência sem conhecimentos prévios pode causar danos irreversíveis.

Key words: Ichthyoplankton, Fish reproduction, Parque Nacional de Ilha Grande, Upper Paraná River.

\section{Introduction}

Lagoons in the floodplains of large rivers are known for their importance as natural nurseries for juvenile fish (Welcomme, 1979, 1985; Lowe-McConnell, 1987; Bayley \& Li, 1996). The characteristics of such environments, such as reduced flow and a dense covering of aquatic macrophytes, favor the development of fish larvae. Thus, the lagoons could be considered true nurseries that offer shelter and abundant food, making larval survival possible (Nakatani et al., 1997). Macrophytes supply the substrate for the development of a rich periphytic community, which is fundamental to the diet of larvae, in addition to supplying shelter from predation during the larval stage, at which fish are extremely vulnerable (Agostinho et al., 1997a; Agostinho \& Júlio Jr., 1999).

Ilha Grande National Park is formed by a group of islands and an extensive floodplain. This floodplain has many lakes that have been considered fundamental for the development of young fishes that will later support fishing in the Paraná River channel (Agostinho et al., 1992, 1994). The park is located along a stretch of the Paraná River that was free of dams and, until mid-1998, had a flood regime that dependent only upon the hydrological cycle. Presently, the river flow is managed by the Sérgio Motta Power Plant (Porto Primavera Dam), and the previously frequent floods are now unable to reach the floodplain lakes (Sanches et al., 2006; Gubiani et al., 2007).

This isolation caused by the flow control imposed by dams has had a great impact on fish reproduction (Agostinho et al., 2001, 2003). Without the overflow of the river and consequent flooding of the floodplain, fish eggs and larvae do not reach the lagoons. They instead remain in the main river channel, where they are more susceptible to predation by fish and other aquatic organisms (Sanches et al., 2006). This may reduce diversity and cause the disappearance of species in the area, mainly large migratory fishes that have a life cycle intimately linked to the elevation of the fluviometric level (Agostinho et al., 2003, 2004).

The environments studied here are marginal lakes that differ in their connectivity to the Paraná River, and thus far, studies are lacking regarding ichthyoplankton ecology in these areas. For Saraiva Lake, only the study of Baumgartner et al. $(2004,2008)$ on fish larvae exists, but its data were collected between 1994 and 1995 (before the construction of the Porto Primavera dam). No studies have been done since the dam closed. There are no studies on the ecology of fish larvae in Xambrê Lake.

The objective of this study was to evaluate the spatial and temporal variations in the abundance and diversity of fish larvae in two lagoons with different degrees of connection to the Paraná River. Specific objectives were: i) to determine the spatial and temporal variations in the abundance and assemblage attributes of larval fishes; ii) to analyze the influence of the degrees of connection on larval abundance, and iii) to study relationships between the abundance of larvae and abiotic variables.

\section{Material and Methods}

\section{Study area}

Ilha Grande National Park (PNIG; 78,875 ha) is located between the Brazilian States of Paraná and Mato Grosso do Sul (CORIPA, 2003). It was created in 1997 and is located in the southern part of the upper Paraná River floodplain (2315' to $24^{\circ} 05^{\prime} \mathrm{S}$; $53^{\circ} 40^{\prime}$ to $54^{\circ} 17^{\prime} \mathrm{W}$ ). The National Park is formed by a fluvial archipelago with hundreds of islands, many of which are recent formed. The recent impoundment of the Paraná River by Porto Primavera Dam caused a reduction of this ecosystem's area by 40\% (Agostinho \& Zalewski, 1996).

Saraiva is a natural lake located on the right margin of Ilha Grande and has a permanent connection to the Paraná River. This lake is about $10 \mathrm{~km}$ long and 300 meters wide at its widest point. Its water is dark and clean with large amounts of vegetation on the banks, mainly comprised of Eichornia azurea. Surrounding the lagoon is a dense riparian forest, along with marshes and flood fields, which form mosaics with the semi-deciduous seasonal forest (CORIPA, 2003). Xambrê Lake is an isolated lake that used to connect to the river only during flood periods. It is located on the left margin of the Paraná River and measures approximately $5 \mathrm{~km}$ long and $1 \mathrm{~km}$ wide. It has an extensive floodplain area on its right margin that separates it from the Paraná River. Currently, it is maintained by groundwater and a small stream.

\section{Sampling}

Larvae were caught in four sampling sites, two in each lake (Fig. 1). In the Saraiva Lake, sampling site Saraiva 1 (S1) was located in the middle of the channel that connects the lake to the Paraná River, with approximately 25 meters of margin. This channel is approximately 50 meters wide and 2 meters deep on average, and has dense coverage by aquatic macrophytes. The Saraiva 2 site (S2) is located in the central portion of the lake, about 150 meters from the edge and 3 meters deep. In Xambrê Lake, two sampling sites were also established, Xambrê 1 (X1) and Xambrê 2 (X2). The X1 site was located approximately 20 meters from the margin of the lake, where the water is approximately 1.5 meters deep, and 
exhibits marginal aquatic vegetation, consisting mainly of grasses. The X2 site was located in the central portion of the lake, about 500 meters from the edge and has 3 meters deep on average.

Samples were obtained monthly, in three consecutive spawning seasons of the most common Paraná River fish species (according to Vazzoler, 1996): from October 2001 to March 2002 (spawning season I), from October 2003 to March 2004 (spawning season II), and from October 2004 to March 2005 (spawning season III).

Samples were taken at night with a plankton net $(0.5 \mathrm{~mm}$ mesh size) that was equipped with a flow meter to measure the filtered water volume. The plankton net was towed at the water's surface behind a boat at low speed for $10 \mathrm{~min}$. The samples were transferred to polyethylene flasks and preserved in commercial formalin diluted to $4 \%$ and buffered with calcium carbonate.

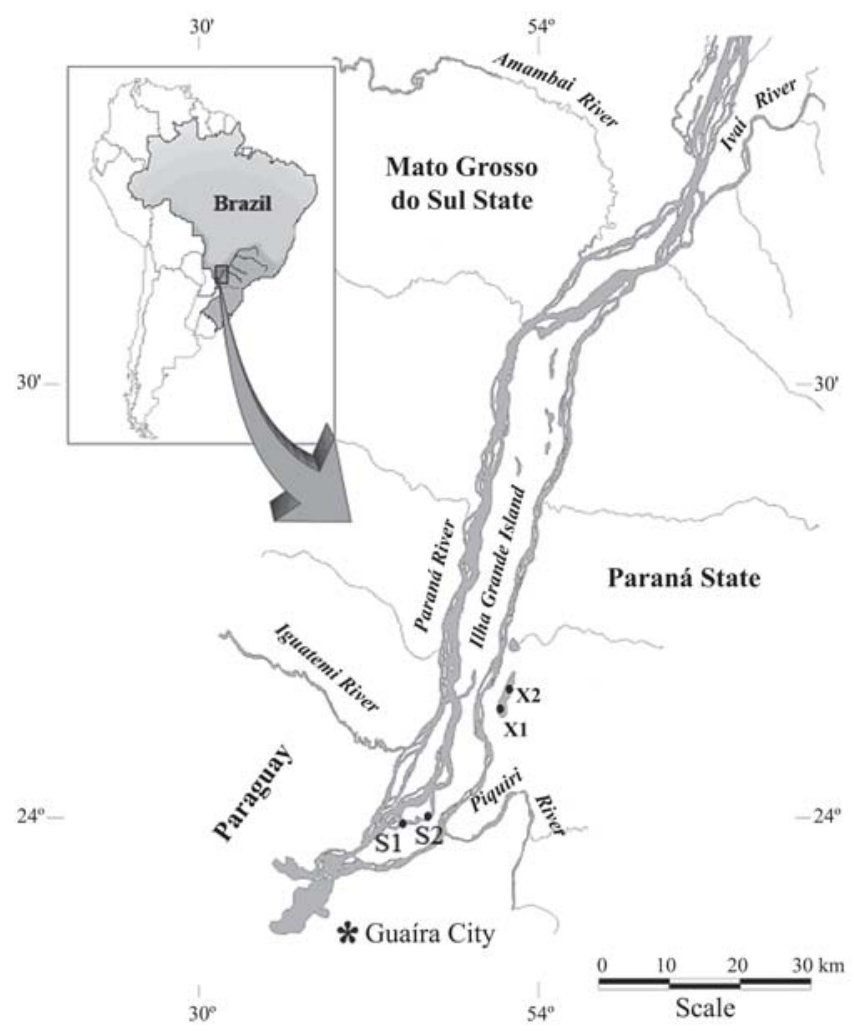

Fig. 1. Locations of the sampling sites in Ilha Grande National Park, upper Paraná River. X1 - Xambrê stream; X2 - Xambrê middle; S1 - Saraiva channel; and S2- Saraiva middle.

\section{Data analyses}

Fish larvae were identified considering all morphometric characteristics according to Nakatani et al. (2001) and the taxonomic framing was based on Reis et al. (2003). The abundance of larvae was standardized to a volume of $10 \mathrm{~m}^{3}$ of filtered water, according to Tanaka (1973), modified by Nakatani et al. (2001).
Species richness (number of species), Shannon Diversity Index

$$
H^{\prime}=-\sum_{i=1}^{s}\left(p_{i}\right) \times \ln p_{i}
$$

(where $s=$ species number and $p_{i}=$ species $i$ proportion), and evenness

$$
E=\frac{H^{\prime}}{\ln S}
$$

(where: $H^{\prime}=$ Shannon Diversity Index and $\mathrm{S}=$ species richness) (Magurran, 1988), were calculated from the sample data for each site.

A non-metric multidimensional scaling algorithm (NMS) (Kruskal 1964a, 1964b) was applied to compare larvae assemblage composition and structure between the sampled lagoons and spawning seasons. Sorensen distances were computed, and we followed the general NMS procedure outlined by McCune \& Grace (2002). We used random starting configurations and completed 100 runs with the sample data. The stability criterion was $\leq 0.005$ standard deviations in stress over 100 iterations. This analysis was performed on the data matrix of abundance, in number, of the collected species in each month and sampling site (by sample). Scores of the NMS axes retained were used in further analyses to determine possible significant temporal and spatial variations in the composition and structure of fish assemblages. Pearson correlations identified the species that most influenced the axes retained for interpretation.

Species richness, H', E, and NMS were computed using the software PC-Ord 4.0 (McCune \& Mefford, 1999). In order to verify whether there were differences between the averages of these variables, as well as between the averages of the scores from the axes retained for interpretation, two-way ANOVAs (Factor 1: site; Factor 2: spawning season; and their interaction) were applied. We tested the assumptions of normality and homoscedasticity using the Shapiro-Wilk and Levene tests, respectively. When the interaction of the two-way ANOVA was not significant, but a factor was, the Tukey test was applied to determine which level differed. Analysis of variance and the correlations were performed using Statistica ${ }^{\mathrm{TM}} 7.0$ software. The statistical significance level adopted was $\mathrm{p}<0.05$.

Simultaneously with the biotic samplings, water parameters such as $\mathrm{pH}$, temperature $\left({ }^{\circ} \mathrm{C}\right)$, conductivity $\left(\mu \mathrm{S} . \mathrm{cm}^{-1}\right)$, and dissolved oxygen (mg. $\mathrm{L}^{-1}$ ) were measured with field equipment. The relationships between environmental conditions and the total abundance of larvae at the four sites were explored through linear statistical models (General Linear Models protocol in Statistica $7.0^{\mathrm{TM}}$ ), according to the model:

$\operatorname{Ln}(A L)=\mu+\alpha_{1} L o c+\alpha_{2} T+\alpha_{3} p H+\alpha_{4} D O+C \alpha_{5}+\alpha_{6} T^{2}+$
$\alpha_{7} p H^{2}+\alpha_{8} D O^{2}+\alpha_{9} E C^{2}+\varepsilon$

where:

$A L=$ Abundance of larvae (larvae $/ 10 \mathrm{~m}^{3}$ );

$\mu$ and $\alpha=$ model parameters; 
$L O C=$ categorical factor: sampling sites;

$T=$ continuous variable: water temperature $\left({ }^{\circ} \mathrm{C}\right)$;

$p H=$ continuous variable: potential of hydrogen;

$D O=$ continuous variable: dissolved oxygen $\left(\mathrm{mg} . \mathrm{L}^{-1}\right)$;

$C=$ continuous variable: conductivity $\left(\mu \mathrm{S} . \mathrm{cm}^{-1}\right)$;

$\varepsilon=$ residue $\left(\varepsilon \sim \mathrm{N}\left(0, \sigma^{2}\right)\right)$.

After the adjustment of the complete model (Least Squares Regression method), the variables that did not result in significant relationships $(\mathrm{p}>0.05)$ were removed until a model with only significant parameters was found. The assumptions of this model $\left(\varepsilon \sim N\left(0, \sigma^{2}\right)\right)$ were checked according to Kéry \& Hatfield (2003).

\section{Results}

\section{Abundance}

During the three spawning seasons in four sampling sites, we caught 12,299 larvae belonging to 29 species, 5 orders and 14 families (Appendix 1). The largest species richness of the captured larvae was observed in spawning season I (27 species), and the smallest was during spawning season II (17 species).

In Xambrê Lake, 1,560 larvae were collected representing 11 taxa, of which nine were identified to the species level and two only to the genus level. However, there was a predominance of Plagioscion squamosissimus, Hypophthalmus edentatus and Catathyridium jenynsii in all spawning seasons studied (Fig. 2a).

In Saraiva Lake, 10,739 larvae were caught and classified in 25 taxa, 20 identified to the species level and five to the genus level. During the study, larvae of both migratory species (such as Salminus brasiliensis and Rhamdia quelen) and sedentary species (Hyphessobrycon sp. and Moenkausia aff. intermedia) were caught (Fig. 2b).

In Xambrê Lake, the X2 site presented the larger mean capture of larvae in all three spawning seasons. The largest mean abundance was registered in X2 (19.37 ind./10 m³). For sites $\mathrm{X} 1$ and $\mathrm{X} 2$ combined, the highest abundance (28.73 ind. $/ 10 \mathrm{~m}^{3}$ ) was observed during spawning season II. The greater average abundance of site X2 was also verified in spawning season II (14.37 ind./10 $\mathrm{m}^{3}$ ) (Fig. 3).

For Saraiva Lake, during all three spawning seasons the greater larvae abundance was recorded at the S1 site. For sites S1 and S2 combined, the largest average abundance was registered in spawning season III $\left(6.65\right.$ ind. $\left./ 10 \mathrm{~m}^{3}\right)$ and the smallest in spawning season II (4.05 ind./10 $\mathrm{m}^{3}$ ) (Fig. 3).

A two-way ANOVA applied to the abundance values presented significant differences between sites (Table 1). The Tukey test revealed that S2 was different from X2. There was no significant difference between sampling periods (Table 1 ). The assumptions of the ANOVA were met (Shapiro-Wilk and Levene: $\mathrm{p}<0.05$ ).

\section{Patterns in species richness, Shannon Diversity Index and evenness}

Species richness by sample differed significantly across
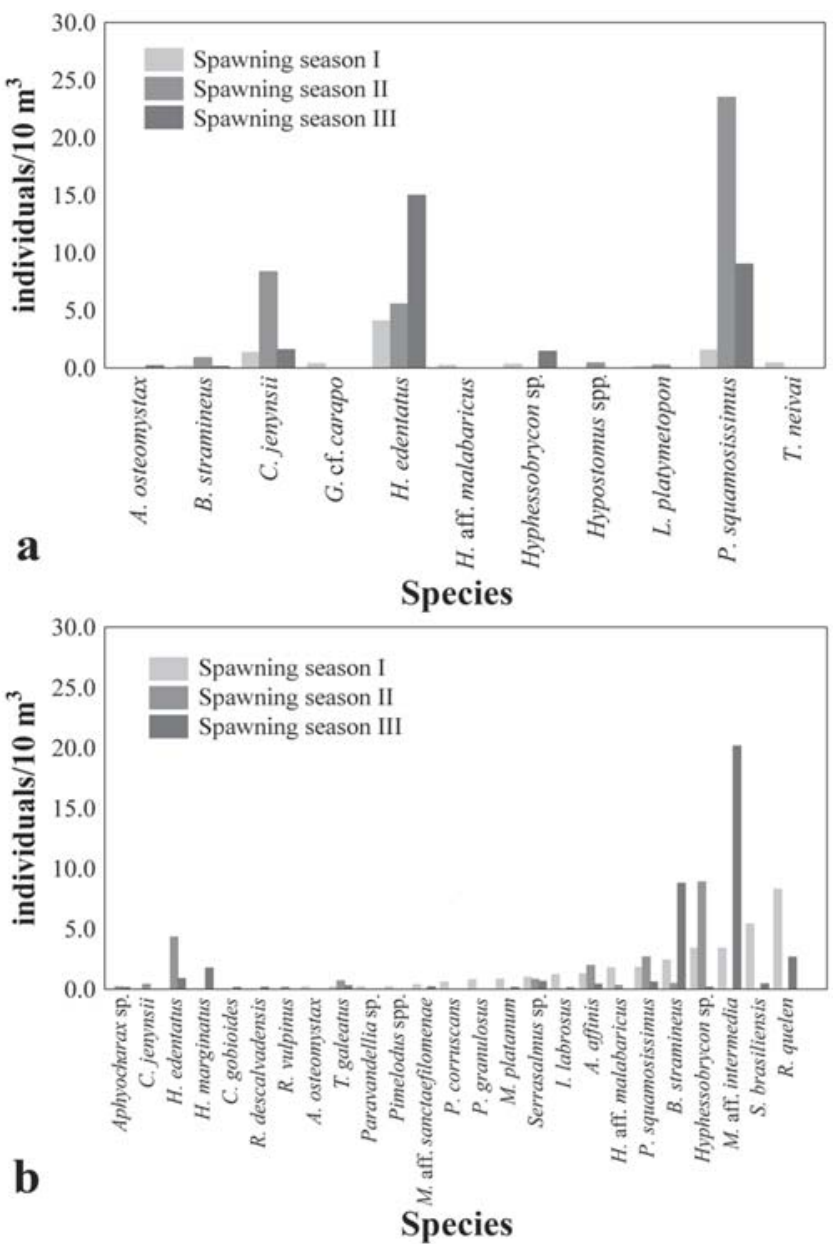

Fig. 2. Larvae abundances for the different species in Xambrê Lake (a) and Saraiva Lake (b) in Ilha Grande National Park, upper Paraná River, during the three studied spawning seasons.

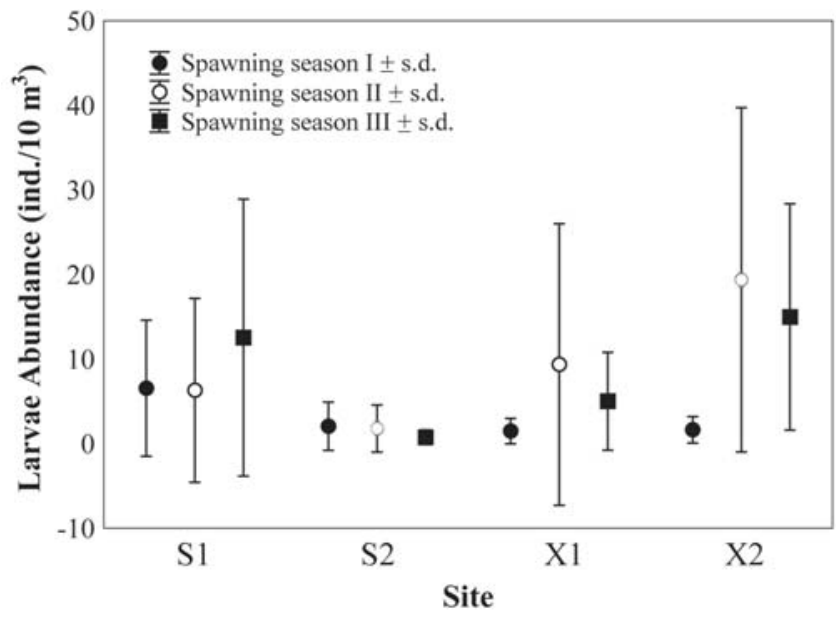

Fig. 3. Variations in mean fish larvae abundance per sampling for Xambrê Lake and Saraiva Lake sites (S1 - Saraiva channel, S2- Saraiva middle, X1 - Xambrê stream and X2 - Xambrê middle) in Ilha Grande National Park, upper Paraná River, during the three studied spawning seasons (s.d. = standard deviation). 
Table 1. Results of two-way ANOVAs evaluating the source of spatial (sites) and temporal (spawning seasons I, II and III) variation in larvae abundance in two lakes with different degrees of connection to the Paraná River. S.S. = sum of squares; d.f. = degrees of freedom; M.S. = mean square; $\mathrm{F}=\mathrm{F}$ statistic; $\mathrm{p}=$ significance level. Values in bold indicate significant differences.

\begin{tabular}{lccccc}
\hline \multicolumn{1}{c}{ Effects } & SS & d.f. & MS & F & p \\
\hline Site & 1076.95 & 3 & 358.98 & 3.13 & $\mathbf{0 . 0 3 2 2}$ \\
Spawning season & 553.48 & 2 & 276.74 & 2.41 & 0.0982 \\
Site*Spawning season & 812.61 & 6 & 135.44 & 1.18 & 0.3288 \\
Error & 6882.85 & 60 & 114.71 & & \\
\hline
\end{tabular}

sites (Table 2). The highest species richness occurred at site $\mathrm{S} 1(\mathrm{~S}=15)$ and the lowest at sites X1 and X2 ( $=3$ ) (Fig. 4a). The Tukey test showed that site $\mathrm{S} 1$ was different from sites $\mathrm{X} 1$ and X2. There was no significant difference across sampling periods (Table 2). The largest value was obtained in spawning season I $(S=15)$, and the smallest value was obtained in spawning seasons II and III (S = 3) (Fig. 4a).

There were no significant differences in evenness (Table 2). For sampling sites, the largest and smallest average values were both registered at site $\mathrm{X} 1(\mathrm{E}=0.751$ and 0.099 , respectively) (Fig. 4b). The highest average value was obtained in spawning season III $(\mathrm{E}=0.687)$ and the lowest in spawning season II ( $\mathrm{E}=0.293$ ) (Fig. 4b).

The Shannon Diversity Index differed significantly between sites, but there were no significant differences between spawning seasons (Table 2). By sampling site, the largest average value was found in $\mathrm{S} 1\left(\mathrm{H}^{\prime}=1.198\right)$ and the smallest in X1 ( $\left.\mathrm{H}^{\prime}=0.081\right)$ (Fig. 4c). A Tukey test showed a significant difference between the Shannon Diversity Indices of S1 and X1. The largest average value per season was

Table 2. Results of two-way ANOVAs evaluating the effects of spatial (sites) and temporal (spawning seasons I, II and III) variation and the interaction between these sources for species richness (number), Shannon Diversity Index and evenness in two lakes with different degrees of connection to the Paraná River. S.S. = sum of squares; d.f. = degrees of freedom; M.S. = mean square; $\mathrm{F}=\mathrm{F}$ statistic; $\mathrm{p}=$ significance level. Values in bold indicate significant differences.

\begin{tabular}{ccccccc}
\hline Variables & Effects & SS & d.f. & MS & F & p \\
\hline \multirow{4}{*}{ S } & Site & 70.69 & 3 & 23.56 & 5.59 & $\mathbf{0 . 0 0 2 2}$ \\
& Spawning season & 4.52 & 2 & 2.26 & 0.54 & 0.5879 \\
& Site* Spawning season & 21.20 & 6 & 3.53 & 0.83 & 0.5461 \\
& Error & 214.95 & 51 & 4.21 & & \\
\hline \multirow{3}{*}{ E } & Site & 0.34 & 3 & 0.11 & 0.92 & 0.4386 \\
& Spawning season & 0.10 & 2 & 0.05 & 0.42 & 0.6563 \\
& Site* Spawning season & 1.45 & 6 & 0.24 & 1.99 & 0.0842 \\
& Error & 6.21 & 51 & 0.12 & & \\
\hline \multirow{3}{*}{$H^{\prime}$} & Site & 2.31 & 3 & 0.77 & 3.43 & $\mathbf{0 . 0 2 3 7}$ \\
& Spawning season & 0.36 & 2 & 0.18 & 0.79 & 0.4554 \\
& Site* Spawning season & 1.41 & 6 & 0.24 & 1.05 & 0.4059 \\
& Error & 11.46 & 51 & 0.22 & & \\
\hline \multirow{2}{*}{ Axis 1 1} & Site & 4351528 & 3 & 1450509 & 60.84 & $\mathbf{0 . 0 0 0 0}$ \\
& Spawning season & 328786 & 2 & 164393 & 6.89 & $\mathbf{0 . 0 0 2 2}$ \\
& Site* Spawning season & 252573 & 6 & 42095 & 1.77 & 0.1249 \\
& Error & 1215889 & 51 & 23841 & & \\
\hline
\end{tabular}

obtained in spawning season I $\left(\mathrm{H}^{\prime}=0.932\right)$ and the smallest average value in spawning season II ( $\left.\mathrm{H}^{\prime}=0.277\right)$ (Fig. 4c).

The assumptions of the ANOVA were met (Shapiro-Wilk and Levene: $\mathrm{p}<0.05$ ) in all analyses of the attributes of larvae assemblages.
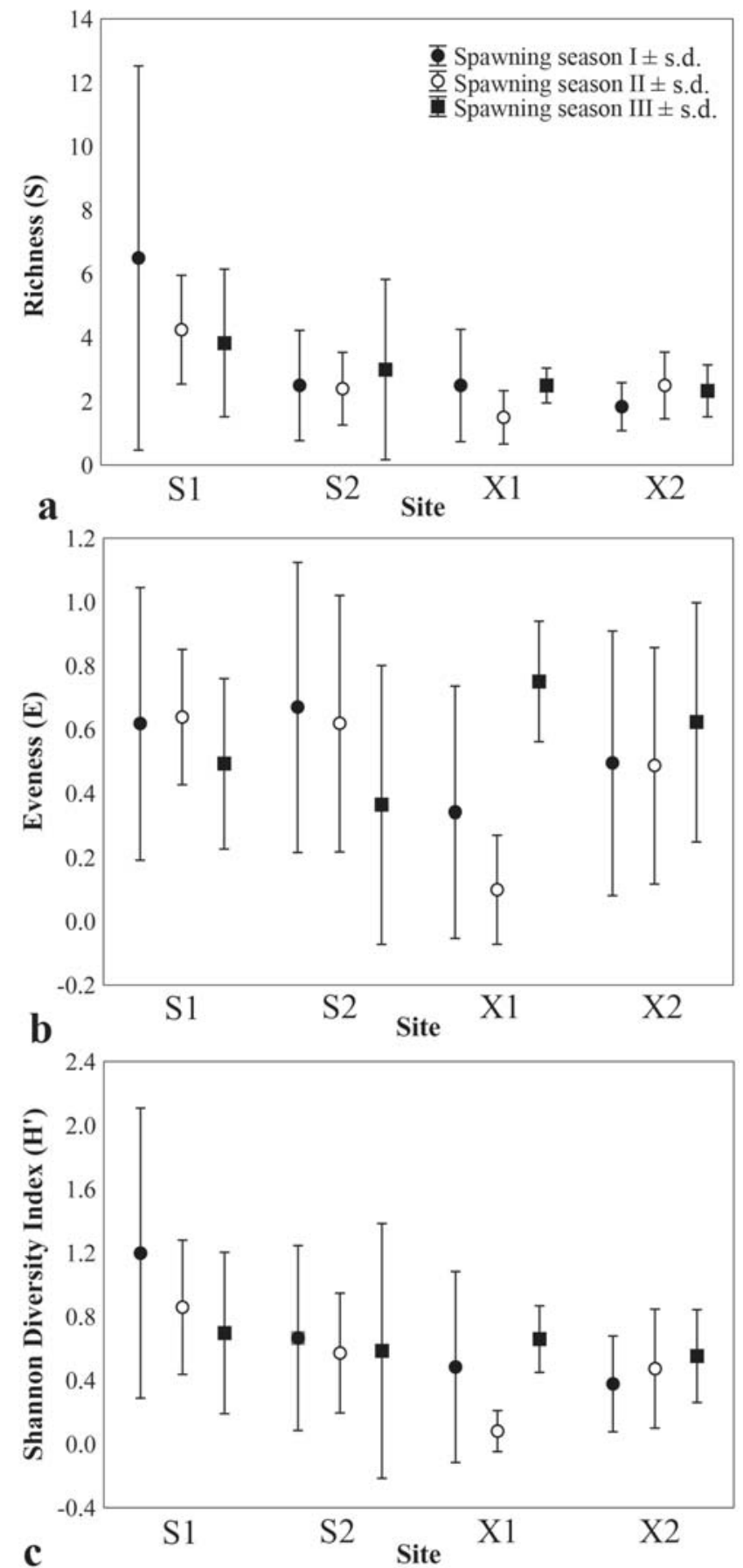

Fig. 4. Variations in mean species richness (number of species) (a), evenness (E) (b) and Shannon Diversity Index (H') (c) of fish larvae per sampling for Xambrê Lake and Saraiva Lake sites (S1 - Saraiva channel, S2 - Saraiva middle, X1 - Xambrê stream and X2 - Xambrê middle) in Ilha Grande National Park, upper Paraná River, during the three studied spawning seasons (s.d. $=$ standard deviation). 


\section{Variations in structure of fish larvae assemblages}

Non-metric multidimensional scaling (NMS) summarized the composition and structure of the fish larvae assemblage at each site (Fig. 5a). After 27 interactions, the stability criterion was met with a final stress of 21.68 (Monte Carlo test: $\mathrm{p}=0.0046$ ) for a three-dimensional solution. Three prevalent gradients explained most of the variance (axes 1, 2 and 3 explained 17.5, 11.7 and $7.4 \%$, respectively) in the analytical data set (cumulative $=36.6 \%$ ).

The location of the points along axis 1 (Fig. 5a) identified sites (spatial scale) as the main pattern in the composition and structure of the fish larvae assemblages. A two-way ANOVA applied to axis 1 scores presented significant differences between sites ( $F=19.48$; $p<0.01$; Fig. 5e; both sites in Saraiva Lake differed from the sites in Xambrê Lake).

Several species presented negative correlations with axis 1 , such as Apareiodon affinis ( $\mathrm{r}=-0.33)$, Serrasalmus sp. $(\mathrm{r}=-0.28)$, Moenkausia aff. sanctaefilomenae $(\mathrm{r}=-0.27)$, and Trachelyopterus galeatus $(\mathrm{r}=-0.27)$, which indicates that they were the most representative in abundance in Saraiva Lake. In contrast, Plagioscion squamosissimus $(\mathrm{r}=0.21)$ was positively correlated with axis 1 . This species was more abundant in Xambrê Lake. No spatial or temporal patterns were observed in axes 2 and 3 (Figs. 5b; 5c; 5d), and no significant difference was observed in the scores, either by axis or by scale (Figs. 5e; 5f; $p>0.05$ ). The assumptions of ANOVA were met in all analyses (Shapiro-Wilk and Levene: $\mathrm{p}<0.05$ ), and moreover, no significant interaction was observed ( $p>0.05$ ).
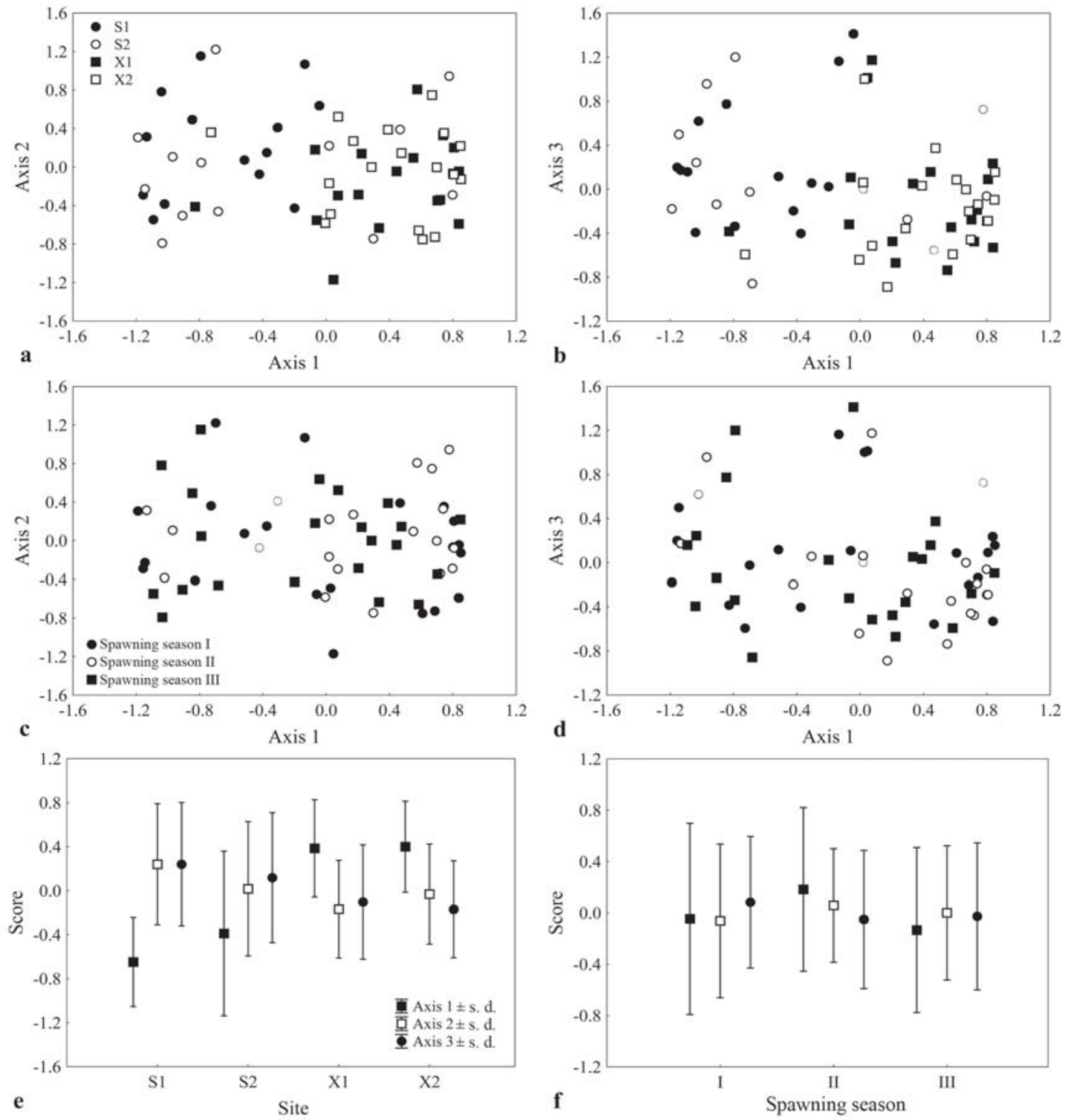

Fig. 5. Sample scores of retained axes (Axes 1, 2, and 3) from the non-metric multidimensional scaling (NMS) controlling for sites (S1 - Saraiva channel, S2 - Saraiva middle, X1 - Xambrê stream and X2 - Xambrê middle) (a; b) and spawning seasons (I, II and III) (c; d). Variation of mean scores axis for sites (e) and spawning seasons (f) in Ilha Grande National Park, upper Paraná River (s.d. = standard deviation). 


\section{Abiotic variables}

The values of abiotic variables are described in Table 3.

\section{Relationships between larvae abundance and abiotic variables}

Total larvae abundance varied among the sampling sites. A positive linear relationship was found between abundance and conductivity, and a quadratic negative relationship was found between abundance and water temperature (Table 4). Together, these factors explain about $40 \%$ of the total variability observed in the abundance of larvae.

Table 3. Monthly mean \pm standard deviation of the abiotic variables during three spawning seasons at four sampling sites.

\begin{tabular}{|c|c|c|c|c|}
\hline & $\begin{array}{c}\text { Abiotic } \\
\text { variables }\end{array}$ & $\begin{array}{c}\text { Spawning } \\
\text { season I }\end{array}$ & $\begin{array}{l}\text { Spawning } \\
\text { season II }\end{array}$ & $\begin{array}{l}\text { Spawning } \\
\text { season III }\end{array}$ \\
\hline & Water temperature & $29.17 \pm 2.54$ & $29.20 \pm 3.03$ & $29.25 \pm 2.75$ \\
\hline Saraiva & $\mathrm{pH} 1$ & $7.47 \pm 0.51$ & $6.78 \pm 0.82$ & $6.78 \pm 0.68$ \\
\hline \multirow[t]{2}{*}{ Channel } & Conductivity & $59.38 \pm 13.53$ & $49.85 \pm 7.06$ & $51.47 \pm 11.63$ \\
\hline & Dissolved oxygen & $8.25 \pm 1.74$ & $6.28 \pm 2.30$ & $7.61 \pm 2.89$ \\
\hline \multirow{4}{*}{$\begin{array}{l}\text { Saraiva } \\
\text { Middle }\end{array}$} & Water temperature & $29.00 \pm 2.39$ & $29.40 \pm 1.51$ & $29.00 \pm 2.70$ \\
\hline & $\mathrm{pH} 1$ & $7.35 \pm 0.24$ & $6.64 \pm 0.81$ & $6.89 \pm 0.60$ \\
\hline & Conductivity & $50.85 \pm 5.97$ & $45.53 \pm 8.11$ & $49.00 \pm 11.98$ \\
\hline & Dissolved oxygen & $8.04 \pm 1.70$ & $7.66 \pm 3.44$ & $7.80 \pm 3.19$ \\
\hline \multirow{4}{*}{$\begin{array}{c}\text { Xambrê } \\
\text { Stream }\end{array}$} & Water temperature & $29.42 \pm 2.48$ & $31.60 \pm 0.89$ & $30.42 \pm 2.97$ \\
\hline & $\mathrm{pH} 1$ & $7.86 \pm 0.25$ & $7.92 \pm 0.88$ & $7.97 \pm 0.98$ \\
\hline & Conductivity & $45.55 \pm 7.63$ & $57.87 \pm 3.51$ & $56.08 \pm 4.96$ \\
\hline & Dissolved oxygen & $8.67 \pm 1.07$ & $7.81 \pm 2.94$ & $7.81 \pm 4.13$ \\
\hline \multirow{4}{*}{$\begin{array}{l}\text { Xambrê } \\
\text { Middle }\end{array}$} & Water temperature & $29.33 \pm 2.27$ & $29.60 \pm 1.52$ & $29.67 \pm 2.34$ \\
\hline & $\mathrm{pH} 1$ & $7.64 \pm 0.67$ & $8.08 \pm 0.83$ & $7.98 \pm 1.22$ \\
\hline & Conductivity & $45.15 \pm 7.43$ & $58.17 \pm 4.36$ & $55.97 \pm 4.71$ \\
\hline & Dissolved oxygen & $8.05 \pm 1.12$ & $8.45 \pm 3.82$ & $8.04 \pm 4.15$ \\
\hline
\end{tabular}

Table 4. Regression results for larvae abundance as a function of water temperature, sampling site and conductivity. The adjusted model shown is significantly related to larvae abundance $\left(\mathrm{F}_{(3,61)}=6.01 ; \mathrm{p}=0.0012\right)$.

\begin{tabular}{lccc}
\hline Ln (Larvae abundance) & Coefficient & $\mathrm{t}$ & $\mathrm{p}>\mathrm{t}$ \\
\hline Water temperature & 2.87 & 1.88 & 0.064 \\
(Water temperature) $^{2}$ & -0.05 & -1.87 & 0.067 \\
Conductivity & 0.08 & 3.97 & $<0.001$ \\
Intercept & -44.58 & -2.01 & 0.049 \\
Site & $\mathrm{F}_{(3,61)}$ & 5.889 & 0.001 \\
\hline
\end{tabular}

\section{Discussion}

The reproductive season for most of the species in the Paraná River floodplain occurs from September to March (Vazzoler, 1996). During the present study, the months with the highest captures of larvae were January, February and March.

The large larvae abundance registered at Saraiva Lake, especially of small, sedentary and opportunistic species belonging mainly to the Characidae family, may be related to its connection with the Paraná River, its dense marginal vegetative covering, and the life strategies of these organisms. This same pattern was verified by Petry et al. (2003) for adult fishes in the upper Paraná River floodplain in a study exploring the role of connectivity in connected and disconnected lagoons. Marginal lagoons in river floodplains are widely recognized for their importance in the maintenance and integrity of regional biodiversity and as preferential habitats of sedentary and small-sized species (Petry et al., 2004). In addition, Ringuelet (1975) affirmed that in habitats with lentic waters and the presence of aquatic vegetation, characids are favored. According to Winemiller (1989), these species achieve greater success in the colonization of these areas because of their high reproductive plasticity, short life cycle and high fecundity. Moreover, in many cases spawning occurs throughout the entire year.

The presence of larvae of migratory species such as Salminus brasiliensis, Pseudoplatystoma corruscans, Pterodoras granulosus and Pimelodus spp. revealed that Saraiva Lake may be considered important for the maintenance of these species. In general, migratory species spawn in the open waters of the main channel or in tributaries, and the eggs and larvae are transported passively by currents to flooded areas and marginal lagoons, where they complete their development (Agostinho et al., 1997a; Nakatani et al., 1997). Therefore, the larvae of migratory species at this lake possibly originated from spawning events that occurred in the Amambaí and Ivinheima rivers, which are tributaries of the right margin of the Paraná river, and are located some kilometers above the lagoon. Sanches et al. (2006) reported that after the closing of Porto Primavera Dam, the larvae of migratory fishes were found in tributaries but were not caught in the main river channel.

The low diversity observed at Xambrê Lake may be attributed to its recent isolation. Before the closing of the Porto Primavera Dam, this lake was connected to the Paraná River during floods, when the populations of the two environments mixed. However, after the closing of the dam and the subsequent flow control imposed on the river, floods were not sufficiently large to reach the lake and the populations were left completely isolated. This lack of connection caused changes in abiotic variables, accessibility, habitat quality and resource availability (Thomaz et al., 1992, 2004; Winemiller et al., 2000; Súarez et al., 2001; Okada et al., 2003). Moreover, Gubiani et al. (2007), studying the persistence of fish populations in an isolated lake in the upper Paraná River floodplain, observed that species decreased in abundance when the flood not happen.

The consequences of this isolation are reflected in the species captured during the study. Migratory species do not reproduce in closed lakes, and moreover, these species will become extinct two years after becoming isolated if there are no floods (Gubiani et al., 2007). The species captured most often were sedentary and characteristic of lentic environments (e.g., Plagioscion squamosissimus, Hypophthalmus edentatus and Catathyridium jenynsii). The prevalence of these species may be related to the nature of their initial development, which favors dispersal to surface waters (Holland, 1986) because of the presence of oil droplets in the eggs (Plagioscion squamosissimus and Catathyridium jenynsii), which increases their buoyancy (Bialetzki et al., 2005).

Another factor that may favor these species is a rich supply of food. In both lakes, there exists a large amount of crustaceans such as shrimp (Macrobrachium amazonicum), which were introduced together with Plagioscion 
squamosissimus in the reservoirs of CESP (Energy Company of São Paulo) in the early 1970s (Bialetzki et al., 2004). Microcrustaceans such as cladocerans and copepods are also abundant, favoring Hypophthalmus edentatus, which is zooplanktophagous (Cavicchioli, 2000; Bialetzki et al., 2005).

The differences observed in the diversity and richness of species among the sampling sites of the two lakes may be related to the characteristics of these sites. Petry et al. (2003) recorded lower species richness, density and biomass in connected lagoons compared to disconnected lagoons for adult fishes in the upper Paraná River floodplain. Site S1 is located in the channel that connects the river to the lake, and because the channel is not very large, it suffers from the effects of the margins being covered with aquatic vegetation, which would favor the development of fish. Thus, site $\mathrm{X} 1$ is influenced by marginal vegetation because it is located near the mouth of a small stream. Sites S2 and X2 are located in the wider portions of the lakes, where the influences of the margins and the vegetation are not so evident. This shows that the establishment of fish communities is strongly influenced by local processes present in the environment (Lyons, 1996; Agostinho et al., 1997b).

The linear model relating the total abundance of larvae to environmental conditions suggests that the highest abundances of larvae are associated with high conductivity values and high water temperatures (i.e., close to $30^{\circ} \mathrm{C}$ ); lower abundance is found when the water becomes excessively hot (close to $36^{\circ} \mathrm{C}$ ). Water temperature is one of the most important factors in the fish life cycle and can speed up or delay metabolic processes. The relationship between larval occurrence and high temperatures has also been documented in other environments in the Paraná River by several authors (Baumgartner et al., 1997; Cavicchioli et al., 1997; Bialetzki et al., 2002). The greatest reproductive intensity of most fish species in the upper Paraná River occurs between October and February (Vazzoler, 1996), when water temperatures are highest. In both lakes, the most favorable environmental conditions for the occurrence of larvae were mainly related to the sampling period, which coincided with times of greater rainfall that contributed to the heating of the water and the increase in conductivity.

Abiotic variables affect the abundance of larvae in several habitats (Oliveira \& Araújo-Lima, 1998). Bialetzki et al. (2005) found strong relationships between the structure of the ichthyoplankton assemblage and environmental variables in the Baia River, mainly related to water temperature, dissolved oxygen, rainfall and current speed. Other studies conducted in the upper Paraná River floodplain also identify these variables as determinants for fish egg and larvae abundance and distribution (Cavicchioli, 2000; Nakatani et al., 2001; Baumgartner, 2001; Castro et al., 2002; Nascimento \& Nakatani, 2006; Sanches et al., 2006; Baumgartner et al., 2008). Furthermore, studies in other basins highlight the importance of environmental variability in the structuring of fish assemblages, mainly for adult fishes (Rodriguez \& Lewis, 1997; Tejerina-Garro et al., 1998; Winemiller et al., 2000; Zeug et al., 2005).
The importance of the connection of the floodplain lakes with the main river and the occurrence of floods that reach the disconnected lagoons was already evidenced in various studies of fish assemblages (Sabo \& Kelso, 1991; Súarez et al., 2004; Amoros \& Bornette, 2002; King et al., 2003; Petry et al., 2003, 2004; Pompeu \& Godinho, 2006; Gubiani et al., 2007). However, specific studies that showed this same pattern for fish larvae assemblages were scarce. In this study, the presence of a connection influenced the diversity and abundance of the fish larvae assemblages, and the flow regulation of the Paraná River by the hydroelectric power stations upstream caused severe alterations in this parameter in disconnected lagoons. The permanent or seasonal connection of the lakes with the river is a determinative factor for the use of these environments as areas of reproduction and larval development for both sedentary and migratory species.

Isolation, such as that which occurred in the Xambrê lagoon, invariably leads to a reduction of diversity, and it favors the proliferation of foraging fishes adapted to lentic environments. The results obtained can also be considered valid for other lakes located in the Ilha Grande National Park, both those recently isolated and those still connected to the river.

\section{Acknowledgements}

The authors acknowledge the financial support of Universidade Paranaense, the team of the Consórcio Intermunicipal para a Conservação do Remanescente das Várzeas do Rio Paraná e Áreas de Influência (CORIPA), the Instituto Ambiental do Paraná (IAP) for supporting the collections, and American Journal Experts (USA) for proofreading the English-language version of the article. G. Baumgartner is grateful to the Conselho Nacional de Desenvolvimento Científico e Tecnológico - Brazil (CNPq) for continuous funding through a Productivity Research Grant.

\section{Literature Cited}

Agostinho, A. A., H. F. Julio Jr. \& J. R. Borghetti. 1992. Considerações sobre os impactos dos represamentos na ictiofauna e medidas para sua atenuação. Um estudo de caso: reservatório de Itaipu. Revista Unimar, 14: 89-107.

Agostinho, A. A., H. F. Julio Jr. \& M. Petrere Jr. 1994. Itaipu reservor (Brazil): Impacts of the impoundment on the fish fauna and fisheries. Pp. 84-171. In: Cowx, I. G. (Ed.). Rehabilitation of freshwater fisheries. Bodman, Fishing News Books, 320p.

Agostinho, A. A., H. F. Júlio Jr., L. C. Gomes, L. M. Bini \& C. S. Agostinho. 1997a. Composição, abundância e distribuição espaço-temporal da ictiofauna. Pp. 179-208. In: Vazzoler, A. E. A. de M., A. A. Agostinho \& N. S. Hahn (Eds.). A planície de inundação do alto rio Paraná: aspectos físicos, biológicos e socioeconomicos. Maringá, Eduem, 460p.

Agostinho, A. A., L. M. Bini \& L. C. Gomes. 1997b. Ecologia de comunidade de peixes da área de influência do Reservatório de Segredo. Pp. 97-111. In: Agostinho, A. A. \& L. C. Gomes (Eds.). Reservatório de Segredo: bases para o manejo. Maringá, Eduem, 386p.

Agostinho, A. A., L. C. Gomes \& M. Zalewski. 2001. The importance 
of floodplains for the dynamics of fish communities of the upper river Paraná. Ecohydrolology \& Hydrobiology, 1(1-2): 209-217.

Agostinho, A. A., L. C. Gomes, H. I. Suzuki \& H. F. Júlio Jr. 2003. Migratory fish from the upper Paraná River basin, Brazil. Pp. 19-99. In: Carolsfeld, J., B. Harvey, C. Ross, A. Baer \& C. Ross (Eds.). Migratory fishes of South America: Biology, Social importance and conservation status. Victoria, World Fisheries Trust, the World Bank and the International Development Research Center, 215p.

Agostinho, A. A., L. C. Gomes, S. Veríssimo \& E. K. Okada. 2004. Flood regime, dam regulation and fish in the Upper Paraná River: effects on assemblage attributes, reproduction and recruitment. Reviews in Fish Biology and Fisheries, 14: 11-19.

Agostinho, A. A. \& M. Zalewski. 1996. A planície alagável do alto Rio Paraná: importância e preservação. Maringá, Eduem, 100p.

Agostinho, A. A. \& H. F. Júlio Jr. 1999. Peixes da bacia do alto rio Paraná. Pp. 374-400. In: Lowe-McConnell, R. H. Estudos ecológicos de comunidades de peixes tropicais. Tradução: Vazzoler, A. E. A. de M., A. A. Agostinho \& P. T. M. Cunnhingham. São Paulo, Edusp, 535p.

Amoros, C. \& G. Bornette. 2002. Connectivity and biocomplexity in waterbodies of riverine floodplains. Freshwater Biology, 47: 761-776.

Baumgartner, G. 2001. Determinação dos locais de desova e criadouros naturais de peixes e influência dos fatores abióticos sobre a abundância de larvas no alto rio Paraná, Brasil. Unpublished Ph.D. Thesis, Universidade Estadual de Maringá, Maringá, 62p.

Baumgartner, G., K. Nakatani, M. Cavicchiolli \& M. S. T. Baumgartner. 1997. Some aspects of the ecology of fish larva in the floodplain of high Paraná River, Brazil. Revista Brasileira de Zoologia, 14: 551-563.

Baumgartner, G., K. Nakatani, L. C. Gomes, A. Bialetzki, P. V. Sanches \& M. C. Makrakis. 2004. Identification of spawning sites and natural nurseries of fishes in the upper Paraná River, Brazil. Environmental Biology of Fishes, 71: 115-125.

Baumgartner, G., K. Nakatani, L. C. Gomes, A. Bialetzki, P. V. Sanches \& M. C. Makrakis. 2008. Fish larvae from the upper Paraná River: do abiotic factors affect larval density? Neotropical Ichthyology, 6(4): 551-558.

Bayley, P. B. \& H. W. Li. 1996. Riverine fishes. Pp. 92-122. In: Calow, P. \& G. Petts (Eds.). River biota: diversity and dynamics. London, Blackwell Science, 257p.

Bialetzki, A., K. Nakatani, P. V. Sanches \& G. Baumgartner. 2002. Spatial and temporal distribution of larvae and juveniles of Hoplias aff. malabaricus (Characiformes, Erythrinidae) in the upper Paraná River floodplain, Brazil. Brazilian Journal of Biology, 62: 211-222.

Bialetzki, A., K. Nakatani, P. V. Sanches \& G. Baumgartner. 2004. Eggs and larvae of the 'curvina' Plagioscion squamosissimus (Heckel, 1840) (Osteichthyes, Sciaenidae) in the Baía River, Mato Grosso do State, Brazil. Journal of Plankton Reseach, 26 (11): 1327-1336.

Bialetzki, A., K. Nakatani, P. V. Sanches, G. Baumgartner \& L. C. Gomes. 2005. Larval fish assemblage in the Baía River (Mato Grosso do Sul State, Brazil): temporal and spatial patters. Environmental Biology of Fishes, 73: 37-47.

Castro, R. J., K. Nakatani, A. Bialetzki, P. V. Sanches \& G. Baumgartner. 2002. Temporal distribution and composition of the ichthyoplankton from Leopold's Inlet on the Upper Paraná River floodplain (Brazil). Journal of Zoology, 256: 437-443.

Cavicchioli, M., K. Nakatani \& O. A. Shibatta. 1997. Morphometric variation of larvae and juveniles of the piranhas Serrasalmus spilopleura and S. marginatus (Characidae: Serrasalminae) of the Paraná basin, Brazil. Ichthyological Exploration of
Freshwaters, 8: 97-106.

Cavicchioli, M. 2000. Mudanças ontogênicas na morfologia do trato digestório e na dieta, e na seletividade alimentar de larvas de peixes do reservatório de Itaipu - rio Paraná, Brasil. Unpublished Ph.D.Thesis, Universidade Estadual de Maringá, Maringá, 62p.

CORIPA - Consórcio Intermunicipal para a Conservação do Remanescente das Várzeas do Rio Paraná e Áreas de Influência. 2003. Zoneamento Ecológico-Econômico (ZEE) das APA'S Intermunicipais de Ilha Grande- PR. Altônia. CD-ROOM.

Gubiani, E. A., L. C. Gomes, A. A. Agostinho \& E. K. Okada. 2007. Persistence of fish populations in the upper Paraná River: effects of water regulation by dams. Ecology of Freshwater Fish, 16(2): 191-197.

Holland, L. E. 1986. Distribuition of early life history of fishes in selected pools of the Upper Mississipi River. Hydrobiologia, 136: 121-130.

Kéry, M. \& J. S. Hatfield. 2003. Normality of raw data in general linear models: the most widespread myth in statistics. Bulletin of the Ecological Society of America, 82: 92-94.

King, A. J., P. Humphries \& P. S. Lake. 2003. Fish recruitment on floodplains: the roles of patterns of flooding and life history characteristics. Canadian Journal of Fisheries and Aquatic Sciences, 60: 773-786.

Kruskal, J. B. 1964a. Multidimensional scaling by optimizing goodness of fit to a nonmetric hypotheses. Psychometrika, 29: 1-27.

Kruskal, J. B. 1964b. Nonmetric multidimensional scaling: a numerical method. Psychometrika, 29: 115-129.

Lowe-McConnell, R. H. 1987. Ecological studies in tropical fish communities. London, Cambridge University Press, 382p.

Lyons, J. 1996. Patterns in the species composition of fish assemblages among Wisconsin streams. Environmental Biology Fishes, 25(4): 329-341.

Magurran, A. E. 1988. Ecological diversity and his measurement. New Jersey, Princeton University Press, 200p.

McCune, B. \& M. J. Mefford. 1999. PC-ORD. Multivariate Analysis of Ecological Data, Version 4. MjM Software Design. Gleneden Beach, Oregon, 237p.

McCune, B. \& J. B. Grace. 2002. Analysis of ecological communities. Gleneden Beach, MJM Press, 300p.

Nakatani, K., G. Baumgartner \& M. Cavicchioli. 1997. Ecologia de ovos e larvas de peixes. Pp. 281-306. In: Vazzoler, A. E. A. de M., A. A. Agostinho \& N. S. Hahn (Eds.). A planície de inundação do alto rio Paraná: aspectos físicos, biológicos e socioeconomicos. Maringá, Eduem, 460p.

Nakatani, K., A. A. Agostinho, G. Baumgartner, A. Bialetzki, P. V. Sanches, M. C. Makrakis \& C. S. Pavanelli. 2001. Ovos e larvas de peixe de água doce: Desenvolvimento e manual de identificação. Maringá, Eduem, 378p.

Nascimento, F. L. \& K. Nakatani. 2006. Relações entre fatores ambientais e a distribuição de ovos e larvae de peixes na subbacia do rio Ivinhema, Estado de Mato Grosso do Sul, Brasil. Acta Scientiarum, 28(2): 117-122.

Okada, E. K., A. A. Agostinho, M. Petrere Jr. \& T. Penczak. 2003. Factors affecting fish diversity and abundance in drying ponds and lagoons in the upper Paraná River basin, Brazil. Ecohydrology \& Hydrobiology, 3: 97-110.

Oliveira, E. C. de \& C. A. R. M. Araújo-Lima. 1998. Distribuição das larvas de Mylossoma aureum e $M$. duriventre (Pisces: Serrasalmidae) nas margens do rio Solimões, AM. Revista Brasileira de Biologia, 58(3): 349-358.

Petry, A. C., A. A. Agostinho \& L. C. Gomes. 2003. Fish assemblages of tropical floodplain lagoons: exploring the role of connectivity 
in a dry year. Neotropical Ichthyology, 1(2): 111-119.

Petry, A. C., F. Abujanra, P. Piana, H. F. Júlio Jr \& A. A. Agostinho. 2004. Fish assemblages of the seasonally isolated lagoons of the upper Paraná river floodplain. Pp. 131-137. In: Agostinho, A. A., L. Rodrigues, L. C. Gomes, S. M. Thomaz \& L. E. Miranda. Structure and functioning of the Paraná river and its floodplain: LTER - site 6 - (PELD sítio 6). Maringá, Eduem, 275p.

Pompeu, P. dos S. \& H. P. Godinho. 2006. Effects of extended absence of flooding on the fish assemblages of three floodplain lagoons in the middle São Francisco, Brazil. Neotropical Ichthyology, 4(4): 427-433.

Reis, R. E., S. O. Kullander \& C. J. Ferraris Jr. (Orgs.). 2003. Check list of the Freshwater Fishes of South and Central America. Porto Alegre, Edipucrs, 729p.

Ringuelet, R. A. 1975. Zoogeografia y ecologia de los peces de aguas continentales de la Argentina y consideraciones sobre las areas ictiologicas de America del Sur. Ecosur, 2(3): 1-122.

Rodriguez, M. A. \& W. M. Lewis. 1997. Structure of fish assemblages along environmental gradients in floodplain lakes of the Orinoco River. Ecological Monographs, 67: 109-128.

Sabo, M. J., \& W. E. Kelso. 1991. Relationships between morphometry of excavated floodplain ponds along the Mississippi River and their use as fish nurseries. Transactions of the American Fisheries Society, 120: 552-561.

Sanches, P. V., K. Nakatani, A. Bialetzki, G. Baumgartner, L. C. Gomes \& E. Antoniassi. 2006. Flow regulation by dams affeting ichthyoplankton: the case of the Porto Primavera Dam, Paraná River, Brazil. River Research and Applications, 22: 555-565.

Súarez, Y. R., M. Petrere Jr. \& A. C. Catella. 2001. Factors determining the structure of fish communities in Pantanal lagoons (MS, Brazil). Fisheries Management and Ecology, 8: 173-186.

Súarez, Y. R., M. P. Junior \& A. C. Catella. 2004. Factors regulating diversity and abundance of fish communities in Pantanal lagoons, Brazil. Fisheries Management and Ecology, 11: 45-50.

Tanaka, S. 1973. Stock assessment by means of ichthyoplankton surveys. FAO Fisheries Technical Paper, 122: 33-51.

Tejerina-Garro, F. L., R. Fortin \& M. A. Rodriguez. 1998. Fish community structure in relation to environmental variation in floodplain lakes of the Araguaia River, Amazon Basin. Environmental Biology of Fishes, 51: 399-410.

Thomaz, S. M., M. C. Roberto, F. A. Lansac Toha, A. F. Lima \& F. A. Esteves. 1992. Características limnológicas de uma estação de amostragem do alto rio Paraná e outra do baixo rio Ivinheima (PR, MS-Brasil). Acta Limnologica Brasiliensia, 4: 32-51.

Thomaz, S. M., T. A. Pagioro, L. M. Bini, M. do C. Roberto \& R. R. de A. Rocha. 2004. Limnology of the Upper Paraná Floodplain habitats: patterns of spatio-temporal variations and influence of the water levels. Pp. 37-42. In: Agostinho, A. A., L. Rodrigues, L. C. Gomes, S. M. Thomaz \& L. E. Miranda. (Eds.). Structure and functioning of the Paraná River and its floodplain. Maringá, Eduem, 275p.

Vazzoler, A. E. A. de M. 1996. Biologia da reprodução de peixes teleósteos: teoria e prática. Maringá, Eduem, 163p.

Welcomme, R. L. 1979. Fisheries ecology of floodplain rivers. New York, Longman, 317p.

Welcomme, R. L. 1985. River fisheries. FAO Fisheries Technical Paper, 262: 1-330.

Winemiller, K. O. 1989. Patterns of variation in life history among South American fishes in seasonal environments. Oecologia, 81: 225-241.

Winemiller, K. O., S. Tarim, D. Shormann \& J. B. Cotner. 2000. Fish assemblage structure in relation to environmental variation among Brazos River oxbow lakes. Transactions of the American Fisheries Society, 129: 451-468.

Zeug, S. C., K. O .Winemiller \& S. Tarim. 2005. Response of Brazos River oxbow fish assemblages to patterns of hydrologic connectivity and environmental variability. Transactions of the American Fisheries Society, 134: 1389-1399.

Accepted July 11, 2009

Published September 30, 2009

Appendix 1. List of species captured in the Ilha Grande National Park.

\begin{tabular}{ll}
\hline Order Characiformes & Loricariichthys platymetopon Isbrücker \& Nijssen, 1979 \\
Family Parodontidae & Family Heptapteridae \\
Apareiodon affinis (Steindachner, 1879) & Rhamdia quelen (Quoy \& Gaimard, 1824) \\
Family Characidae & Family Pimelodidae \\
Aphyocharax sp. & Hypophthalmus edentatus Spix \& Agassiz, 1829 \\
Bryconamericus stramineus Eigenmann, 1908 & Iheringichthys labrosus (Lütken, 1874) \\
Hemigrammus marginatus Ellis, 1911 & Megalonema platanum (Günther, 1880) \\
Hyphessobrycon sp. & Pimelodus spp. \\
Moenkhausia aff. intermedia Eigenmann, 1908 & Pseudoplatystoma corruscans (Spix \& Agassiz, 1829) \\
Moenkhausia aff. sanctaefilomenae (Steindachner, 1907) & Family Doradidae \\
Roeboides descalvadensis Fowler, 1932 & Pterodoras granulosus (Valenciennes, 1821) \\
Salminus brasiliensis (Cuvier, 1816) & Family Auchenipteridae \\
Serrasalmus sp. & Auchenipterus osteomystax (Ribeiro, 1918) \\
Family Cynodontidae & Trachelyopterus galeatus (Linnaeus, 1766) \\
Rhaphiodon vulpinus Agassiz, 1829 & Tatia neivai (Ihering, 1930) \\
Family Erythrinidae & Order Gymnotiformes \\
Hoplias aff. malabaricus (Bloch, 1794) & Family Gymnotidae \\
Order Siluriformes & Gymnotus cf. carapo Linnaeus, 1758 \\
Family Cetopsidae & Order Perciformes \\
Cetopsis gobioides Kner, 1858 & Family Sciaenidae \\
Family Trichomycteridae & Plagioscion squamosissimus (Heckel, 1840) \\
Paravandellia sp. & Order Pleuronectiformes \\
Family Loricariidae & Family Achiridae \\
Hypostomus spp. & Catathyridium jenynsii (Günther, 1862) \\
\hline
\end{tabular}

